\title{
A survey to describe sleep-facilitating substances used by Canadian emergency physicians
}

\author{
Benoit Bailey, MD, MSc; ${ }^{* \dagger}$ Lubomir Alexandrov, M Math ${ }^{\dagger}$
}

\begin{abstract}
Background: Because night shifts disrupt the normal circadian rhythm, sleep management is crucial for emergency physicians. The purpose of the survey was to describe the use of sleep-facilitating substances (SFSs) by emergency physicians before or after a night shift and to evaluate factors associated with their use.

Methods: All members of the Canadian Association of Emergency Physicians with a Canadian postal address were mailed a copy of the survey. Canadian physicians were eligible if they worked at least one night shift per month and spent $50 \%$ or more of their time in emergency medicine. Logistic regression was used to identify characteristics most predictive of using SFSs before or after a night shift.

Results: Of the 1621 surveys mailed, 805 were returned completed, for a response rate of $49.6 \%$. Of these, 628 respondents met inclusion criteria and 215 respondents (34\%) reported consuming at least one SFS in their career to help them sleep around a night shift. The use of an SFS before a night shift was associated with the use of SFSs after a night shift (odds ratio [OR] 3.8; 95\% confidence interval $[\mathrm{Cl}] 2.4-5.9)$ and the use of SFSs at other times (OR 3.8; $95 \% \mathrm{Cl} 2.1-6.6)$. The use of SFSs after a night shift was associated with the use of a sleep-facilitating technique before a night shift (OR 2.1; 95\% Cl 1.3-3.3); use of an SFS before a night shift (OR 4.0; 95\% Cl 2.4-6.4); use of SFSs at other times (OR 4.7; $95 \% \mathrm{Cl} 2.6-8.4)$; and success of a nap before the night shift (OR 0.46; $95 \% \mathrm{Cl} 0.25-0.83)$.

Conclusion: The rate of SFS use is similar in emergency physicians and other shift workers. Emergency physicians who use SFSs before or after a night shift are more likely to use them at other times as well, and less likely to use them if they nap successfully prior to a night shift.
\end{abstract}

Key words: shift work; emergency medicine; sleeping aids

\section{RÉSUMÉ}

Contexte : Étant donné que les quarts de nuit perturbent le rythme circadien normal, il est primordial pour le médecin d'urgence de gérer son sommeil. Le présent sondage avait comme objectif de décrire le recours aux somnifères par les médecins d'urgence avant et après un quart de nuit et d'évaluer les facteurs associés à leur utilisation.

Méthodes: Tous les membres de l'Association canadienne des médecins d'urgence ayant une adresse postale canadienne reçurent un exemplaire du sondage par la poste. Les médecins canadiens étaient admissibles s'ils assuraient au moins un quart de nuit par mois et consacraient $50 \%$ ou

*Division of Emergency Medicine and the Division of Clinical Pharmacology and Toxicology, Department of Pediatrics, Hôpital Ste-Justine, Université de Montréal, Montréal, Que.

tResearch Centre, Hôpital Ste-Justine, Université de Montréal, Montréal, Que.

Received: May 27, 2004; final submission: Nov. 11, 2004; accepted: Nov. 15, 2004

This article has been peer reviewed.

Can J Emerg Med 2005;7(2):93-102 
plus de leur temps à la médecin d'urgence. On eut recours à la régression logistique pour établir les caractéristiques les plus prédictives quant au recours aux somnifères avant et après un quart de nuit.

Résultats : Huit cent cinq des 1621 sondages envoyés nous furent retournés dûment remplis, pour un taux de réponse de 49,6\%. Parmi ceux-ci, 628 répondants satisfaisaient aux critères d'inclusion et 215 répondants (34\%) disaient avoir consommé au moins un type de somnifère au cours de leur carrière pour les aider à dormir avant et après un quart de nuit. L'utilisation d'un somnifère avant un quart de nuit était associée à son utilisation après un quart de nuit (rapport de cotes $[R C] 3,8$; intervalle de confiance [IC] de $95 \% 2,4-5,9$ ) et à son utilisation en d'autres temps (RC 3,8; IC $95 \% 2,1-6,6)$. Le recours à un somnifère après un quart de nuit était associé au recours à une technique d'aide au sommeil avant un quart de nuit (RC 2,1; IC $95 \%$ 1,3-3,3); le recours à un somnifère avant un quart de nuit (RC 4,0; IC $95 \%$ 2,4-6,4); le recours à un somnifère en d'autres temps (RC 4,7; IC $95 \%$ 2,6-8,4); et le succès d'une sieste avant un quart de nuit (RC 0,46; IC $95 \% 0,25-0,83)$.

Conclusion : Le pourcentage de recours aux somnifères est similaire chez les médecins d'urgence et chez les autres travailleurs par quarts. Les médecins d'urgence qui utilisent des somnifères avant ou après un quart de nuit sont plus susceptibles de les utiliser aussi en d'autres temps et moins susceptibles de les utiliser s'ils réussissent à faire une sieste avant leur quart de nuit.

\section{Introduction}

Emergency physicians care for acutely ill patients on a 24 hours a day, 365 days per year basis. They work day, evening and night shifts in diverse shifting patterns. Night shifts are especially difficult because they are often busy and night-shift physicians typically work alone. Furthermore, night shifts disrupt normal circadian rhythms; therefore, sleep management is crucial.

Self-medication is one of the strategies used to cope with shift work and the related sleep disruption $;^{1-5}$ however, there is no information available on the prevalence of use of sleep-facilitating medications by emergency physicians. The purpose of this survey was to describe the use of sleep-facilitating substances (SFSs) and sleep-facilitating techniques by emergency physicians, and to identify factors associated with their use. Our hypothesis was that most emergency physicians use SFSs in order to deal with sleep disturbances related to shift work.

\section{Methods}

In April 2003, a cross-sectional survey and an introductory letter were mailed to all Canadian Association of Emergency Physicians (CAEP) members who had a Canadian postal address. In order to ensure confidentiality, the survey was sent only once and both the survey and the returned envelope were unmarked. The survey was pretested and took 3 to 4 minutes to complete. We excluded physicians who worked less than one night shift per month, those who worked less than half time in an emergency department, and those practising outside of Canada.
This survey was approved by our hospital's research ethics committee.

The survey elicited information on age, family status, medical practice and sleep habits before and after a night shift (see online e-Appendix 1 at www.caep.ca/cjem). Respondents were also asked to describe their use of SFSs or sleep-facilitating techniques to enhance sleep before or after a night shift. Study data included descriptions of the specific substances used (barbiturates, benzodiazepines, antihistamines, other sedative-hypnotics, alternative medications, alcohol or marijuana) and time since last use, stratified in the following manner: more than one year, less than one year, or less than one month.

Two separate logistic models were used to analyze the data. 1) The first model assessed the relationship between personal and emergency medicine practice characteristics (independent variables) with the use of SFSs before a night shift at any time during their career (dependent variable). 2) The second regression model assessed the relationship of these independent variables with the use of SFSs after a night shift at any time during their career (dependent variable). Variables significantly associated $(p<0.05)$ with the use of SFSs before (or after) a night shift by univariate analysis were incorporated in a logistic regression model. Interactions were evaluated, and variables were retained if they remained significant at $p<0.05$.

\section{Results}

Of 1634 surveys sent, 11 were undeliverable; 805 of the remaining 1623 were completed and returned, for a response rate of $49.6 \%$. Of the 805 who responded, 628 
(78\%) met the study inclusion criteria.

Table 1, Table 2 and Table 3 summarize demographic characteristics, practice variables and SFS use for the study sample, and show the results of the univariate analysis. One hundred and fifty-two (24\%) respondents reported using sleep-facilitating techniques other than SFSs to help them sleep before or after a night shift. These techniques included relaxation in 35 cases $(23 \%)$, reading in $31(20 \%)$, listening to music in $25(16 \%)$, exercise in $18(12 \%)$, and television, white noise or meditation each with $10(7 \%)$.

A total of 215 emergency physicians (34\%) had consumed at least one SFS in their career to help them sleep before or after a night shift (Table 4).

Among the 215 users, 26 (12\%) always used SFSs before a night shift, 26 (12\%) used SFSs most of the time, 27
$(13 \%)$ used SFSs some of the time, 39 (18\%) used SFSs exceptionally, and 97 (45\%) never used SFSs before a night shift.

Among the 215 users, 4 (2\%) always used SFSs after a night shift, 26 (12\%) used SFSs most of the time, $56(26 \%)$ used SFSs some of the time, 71 (33\%) used SFSs exceptionally, and $58(27 \%)$ never used SFSs after a night shift.

The most frequently used SFSs were dimenhydrinate, by 100 physicians (47\%), zopiclone by 75 (35\%), wine by 56 (26\%), lorazepam by $54(25 \%)$, diphenhydramine by 54 (25\%), beer by $47(22 \%)$ and melatonin by $43(20 \%)$.

One hundred and forty-one emergency physicians $(66 \%$ of respondents who used SFSs before or after a night shift, or $22 \%$ of all respondents) had consumed at least one substance within the past month. The proportion of

\begin{tabular}{|c|c|c|c|}
\hline \multirow[b]{2}{*}{ Factor } & \multirow{2}{*}{$\begin{array}{l}\text { No. (and \%) } \\
\text { of EPs }\end{array}$} & \multicolumn{2}{|c|}{ Use of SFSs, crude OR $(95 \% \mathrm{Cl})$} \\
\hline & & Before night shift & After night shift \\
\hline \multicolumn{4}{|l|}{ Age, yr } \\
\hline$\geq 50$ & $71(11)$ & $1.02(0.29,3.6)$ & $1.5(0.37,5.9)$ \\
\hline $40-49$ & $212(34)$ & $0.91(0.27,2.9)$ & $2.0(0.56,7.1)$ \\
\hline $30-39$ & $329(52)$ & $0.5(0.16,1.7)$ & $1.2(0.32,4.2)$ \\
\hline $20-29$ & $16(2)$ & 1.0 & 1.0 \\
\hline \multicolumn{4}{|l|}{ Marital status } \\
\hline Single & $100(16)$ & $1.2(0.42,4.2)$ & $0.77(0.31,2.0)$ \\
\hline Married & $497(79)$ & $1.0(0.36,2.7)$ & $0.77(0.33,1.8)$ \\
\hline Separated / Divorced & $27(4)$ & 1.0 & 1.0 \\
\hline \multicolumn{4}{|l|}{$\begin{array}{l}\text { Province/Territory } \\
\text { of practice }\end{array}$} \\
\hline $\begin{array}{l}\text { British Columbia } \\
\text { or Yukon }\end{array}$ & $112(18)$ & $2.9(1.2,6.7)$ & $1.8(0.91,3.8)$ \\
\hline Alberta & $84(13)$ & $1.5(0.59,3.8)$ & $1.2(0.59,2.7)$ \\
\hline $\begin{array}{l}\text { Saskatchewan } \\
\text { or Manitoba }\end{array}$ & $36(6)$ & $1.4(0.43,4.3)$ & $1.0(0.37,2.7)$ \\
\hline Ontario & $297(47)$ & $1.3(0.59,2.8)$ & $1.0(0.53,1.96)$ \\
\hline Quebec & $36(6)$ & $2.3(0.77,6.7)$ & $0.83(0.30,2.3)$ \\
\hline Atlantic provinces & $63(10)$ & 1.0 & 1.0 \\
\hline \multicolumn{4}{|l|}{$\begin{array}{l}\text { Year of beginning } \\
\text { practice }\end{array}$} \\
\hline$\leq 1979$ & $47(8)$ & $2.2(1.0,4.8)$ & $1.7(0.77,3.7)$ \\
\hline 1980-1989 & $166(26)$ & $1.24(0.67,2.2)$ & $1.8(1.03,3.1)$ \\
\hline 1990-1999 & $284(45)$ & $1.1(0.66,2.0)$ & $1.5(0.91,2.5)$ \\
\hline 2000-2003 & $130(21)$ & 1.0 & 1.0 \\
\hline \multicolumn{4}{|l|}{ Diploma } \\
\hline FRCPC (EM) & $129(20)$ & $1.4(0.77,1.7)$ & $1.2(0.67,2.1)$ \\
\hline FRCPC (Peds) & $16(2)$ & $2.0(0.59,6.7)$ & $0.5(0.11,2.3)$ \\
\hline CCFP (EM) & $349(56)$ & $1.5(0.83,2.6)$ & $1.2(0.77,2.0)$ \\
\hline Other & $133(21)$ & 1.0 & 1.0 \\
\hline
\end{tabular}


respondents who reported using SFSs at times other than before or after a night shift among all was: $8(1 \%)$ most of the time, $63(10 \%)$ some of the time and 104 (17\%) exceptionally. Seventy-seven percent (447) of the respondents never used SFSs at any time other than before or after a night shift.

Table 5 demonstrates the multiple logistic regression models of variables associated with the use of SFSs before and after a night shift.

\section{Discussion}

Our survey demonstrates that a minority (22\%) of emer- gency physicians reported using SFSs before or after a night shift within the month preceding the survey. Overall, $13 \%$ regularly use SFSs before night shifts, $14 \%$ after night shifts, and $11 \%$ at other times. This is a surprisingly low rate of use given the ease of access that emergency physicians have to SFSs.

Sleep disturbance is a common complication of shift work. ${ }^{6}$ Between $40 \%$ and $80 \%$ of industrial night workers report disturbed sleep compared with $10 \%$ to $15 \%$ of day workers. ${ }^{7}$ Sleep for shift workers is reduced in length by 1 to 4 hours, with the reduction mainly affecting stage 2 and REM sleep. Our data suggest that most emergency physicians are subject to the same concerns. Our logistic regres-

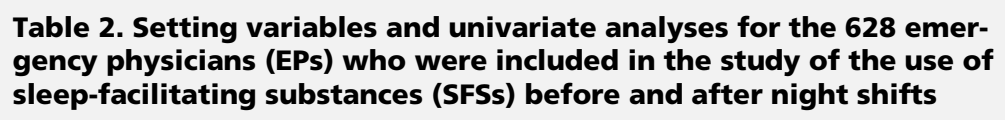

\begin{tabular}{|c|c|c|c|}
\hline \multirow[b]{2}{*}{ Factor } & \multirow{2}{*}{$\begin{array}{l}\text { No. (and } \% \text { ) } \\
\text { of EPs }\end{array}$} & \multicolumn{2}{|c|}{ Use of SFSs, crude OR $(95 \% \mathrm{Cl})$} \\
\hline & & Before night shift & After night shift \\
\hline \multicolumn{4}{|c|}{ Type of practice } \\
\hline Rural & $78(12)$ & $0.67(0.33,1.3)$ & $1.5(0.91,2.5)$ \\
\hline City & $525(84)$ & 1.0 & 1.0 \\
\hline Non-teaching & $177(28)$ & $1.0(0.67,1.6)$ & $1.2(0.83,1.8)$ \\
\hline Teaching & $371(59)$ & 1.0 & 1.0 \\
\hline \multicolumn{4}{|c|}{$\begin{array}{l}\text { No. of patients seen } \\
\text { per year in } E D\end{array}$} \\
\hline$\leq 24999$ & $55(9)$ & $0.48(0.18,1.3)$ & $1.1(0.43,2.6)$ \\
\hline $25000-49999$ & $296(47)$ & $0.71(0.34,1.4)$ & $1.0(0.50,2.0)$ \\
\hline $50000-74999$ & $197(31)$ & $0.59(0.28,1.3)$ & $0.77(0.37,1.6)$ \\
\hline$\geq 75000$ & $46(7)$ & 1.0 & 1.0 \\
\hline \multicolumn{4}{|c|}{$\begin{array}{l}\text { No. of night shifts } \\
\text { per year }\end{array}$} \\
\hline $12-23$ & $80(13)$ & $1.0(0.43,2.2)$ & $0.71(0.31,1.6)$ \\
\hline $24-35$ & $165(26)$ & $0.83(0.42,1.8)$ & $0.83(0.40,1.6)$ \\
\hline $36-47$ & $156(25)$ & $0.67(0.32,1.4)$ & $1.0(0.53,2.1)$ \\
\hline $48-59$ & $117(19)$ & $0.71(0.34,1.6)$ & $1.2(0.59,2.4)$ \\
\hline $60-71$ & $53(8)$ & $0.53(0.19,1.4)$ & $0.71(0.27,1.8)$ \\
\hline$\geq 72$ & $57(9)$ & 1.0 & 1.0 \\
\hline \multicolumn{4}{|l|}{$\begin{array}{l}\text { Duration of the } \\
\text { night shift, hr }\end{array}$} \\
\hline$\geq 12.5$ & $32(5)$ & $0.38(0.11,1.3)$ & $1.8(0.83,4.0)$ \\
\hline $10.5-12$ & 77 (12) & $0.63(0.31,1.2)$ & $1.3(0.77,2.3)$ \\
\hline $8.5-10$ & $186(30)$ & $0.83(0.50,1.3)$ & $1.3(0.83,2.0)$ \\
\hline$\leq 8$ & $330(52)$ & 1.0 & 1.0 \\
\hline \multicolumn{4}{|c|}{$\begin{array}{l}\text { No. of consecutive } \\
\text { night shifts }\end{array}$} \\
\hline 1 & $183(29)$ & $1.0(0.36,2.9)$ & $0.83(0.29,2.4)$ \\
\hline 2 & $301(48)$ & $0.56(0.19,1.8)$ & $1.1(0.38,3.0)$ \\
\hline 3 & $90(14)$ & $0.83(0.28,2.6)$ & $1.2(0.42,3.7)$ \\
\hline 4 & $29(5)$ & $0.83(0.22,3.2)$ & $2.0(0.56,6.7)$ \\
\hline$\geq 5$ & $21(3)$ & 1.0 & 1.0 \\
\hline
\end{tabular}


sion analysis suggests that physicians who use SFSs before night shifts are more likely to use them after night shifts and at other times, and that a successful nap before night shift decreases the use of SFSs after the shift.

Age and years in practice were not associated with SFS use. Conventional wisdom suggests that the burden of night shifts becomes greater with age, yet our data do not show higher rates of SFS use among older emergency physicians. Perhaps these physicians have adopted other lifestyle or practice changes to mitigate the impact of night shifts, but these were not evaluated in our study.

Physicians as a group are relatively heavy users of psychoactive medications. ${ }^{8-10}$ In one study, $37 \%$ of physicians reported sleeping pill or tranquilizer use (within the preceding year) compared to $21 \%$ of the general population. ${ }^{8}$ Other investigators have concluded that, despite higher rates of alcoholism than the general population, physicians are not at substantially higher risk of drug addiction. ${ }^{11}$ The use of SFSs by Canadian emergency physicians is therefore not out of keeping with the use of medications for this purpose by physicians in general.

Emergency physicians' use of SFSs is comparable to other night-shift workers and to the general population. A study from France showed that $15 \%-18 \%$ of nurses working permanent nights used hypnotics or tranquilizers in 1980, 1985 and $1990 .{ }^{12}$ Other data from the same time periods showed that $4 \%-8 \%$ of nurses working alternating night shifts (more similar to emergency physician shifting patterns) used hypnotics or tranquilizers; however, this study did not evaluate alcohol, over-the-counter (OTC) medications or alternative medications. ${ }^{12}$ In a telephone survey of Detroit residents in the age range of 18 to $45,26 \%$ of respondents reported using SFSs during the last year. Overall, $13 \%$ used alcohol and $18 \%$ used other medications, including prescription $(5 \%)$ and OTC (10\%) medications. ${ }^{13}$ In the Detroit study, respondents who worked evening, night or rotating shifts used al-

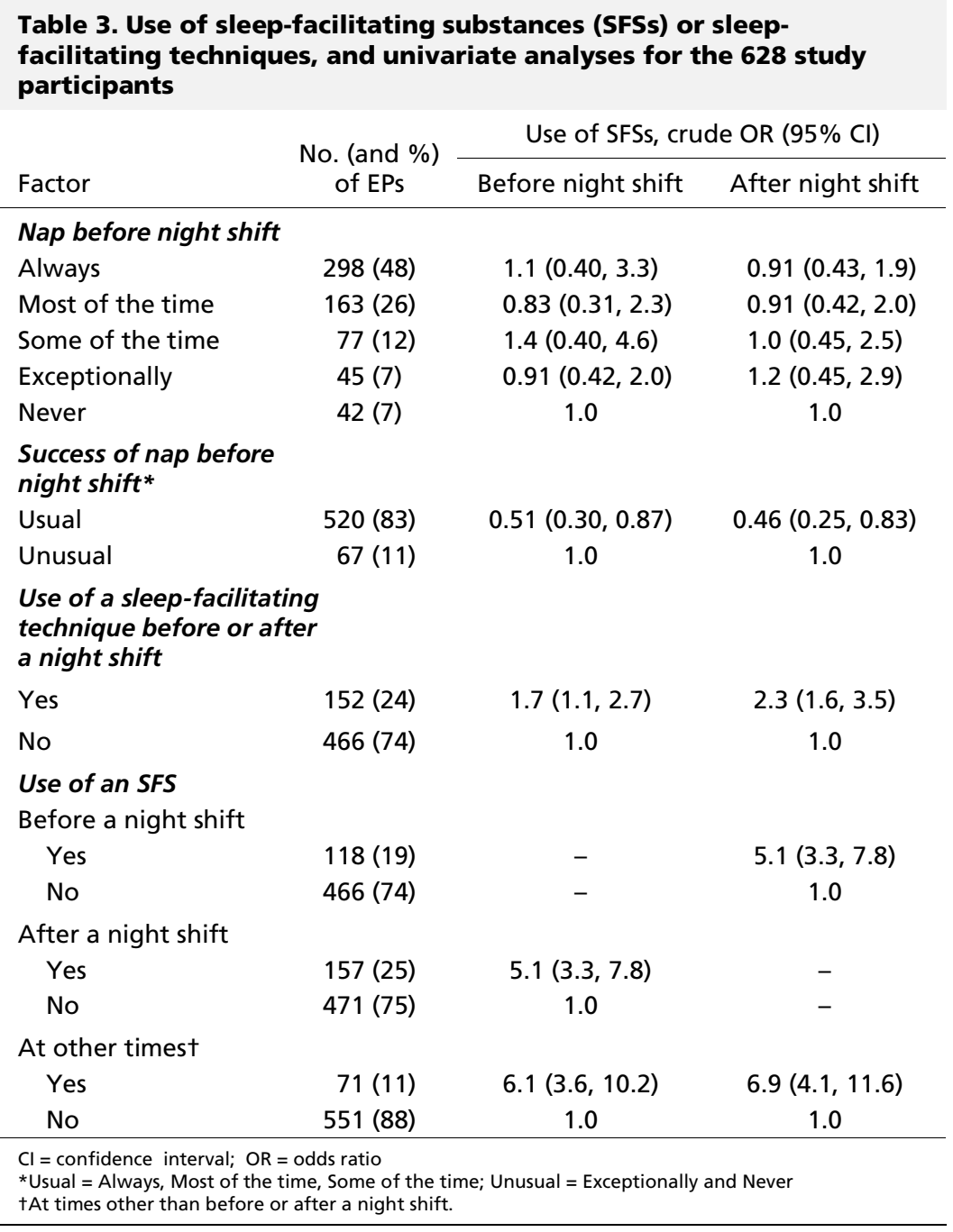


cohol more than day workers or non-workers, and in a US national survey of the general population, $16 \%-28 \%$ of respondents used alcohol as a sleep aid and 22\%-29\% used OTC medications. ${ }^{14,15}$ In a report on two studies of university students, $7 \%$ of respondents used OTC medications as sleep aids and $11 \%$ used alcohol (within the preceding year); however, prescription medication and illicit drug use was not specified in that study. ${ }^{16}$

\section{Limitations}

Although our response rate was excellent for a survey with only one mailing, it is possible that non-respondents had different patterns of SFS use. Further, despite the con- fidential nature of the study, it is possible that some physicians were reticent to reveal true SFS use. We only evaluated the members of one national association of emergency physicians (i.e., CAEP). Finally, our analysis looked only at correlates of SFSs before or after a night shift. Had we studied use over shorter time periods, our findings may have differed.

\section{Conclusion}

Despite having easy access, emergency physicians' use of SFSs appears comparable to other night-shift workers. Emergency physicians who use SFSs before or after a

\begin{tabular}{|c|c|c|c|c|}
\hline \multirow[b]{2}{*}{ Substance } & \multicolumn{3}{|c|}{ Time since last use, no. of EPs } & \multirow{2}{*}{$\begin{array}{c}\text { Total no. of } \\
\text { EPs who } \\
\text { have used } \\
\text { each SFS* }\end{array}$} \\
\hline & $>1$ year & $\begin{array}{l}\text { Within } \\
\text { the past } \\
\text { year }\end{array}$ & $\begin{array}{l}\text { Within the } \\
\text { past month }\end{array}$ & \\
\hline Benzodiazepines & 43 & 29 & 45 & 117 \\
\hline Other sedative-hypnotics & 17 & 34 & 55 & 106 \\
\hline Antihistamines & 44 & 58 & 55 & 157 \\
\hline Alternative medications & 36 & 18 & 25 & 79 \\
\hline Alcohol & 29 & 34 & 72 & 135 \\
\hline Marijuana & 5 & 2 & 2 & 9 \\
\hline Other SFSs & 4 & 3 & 6 & 13 \\
\hline Total* & 178 & 178 & 260 & 616 \\
\hline
\end{tabular}

\begin{tabular}{|c|c|c|}
\hline Variable & $\begin{array}{l}\text { Crude OR } \\
(95 \% \mathrm{Cl})\end{array}$ & $\begin{array}{l}\text { Adjusted OR } \\
(95 \% \mathrm{Cl})\end{array}$ \\
\hline \multicolumn{3}{|l|}{$\begin{array}{l}\text { Use of an SFS before a night shift, } \\
\text { in relation to }\end{array}$} \\
\hline - $\quad$ use of an SFS after a night shift & $5.1(3.3,7.8)$ & $3.8(2.4,5.9)^{*}$ \\
\hline - use of an SFS at other times & $6.1(3.6,10.2)$ & $3.8(2.1,6.6)^{*}$ \\
\hline \multicolumn{3}{|l|}{$\begin{array}{l}\text { Use of an SFS after a night shift, } \\
\text { in relation to }\end{array}$} \\
\hline $\begin{array}{l}\text { use of a sleep-facilitating tech- } \\
\text { nique to help sleep before a } \\
\text { night shift }\end{array}$ & $2.3(1.6,3.5)$ & $2.1(1.3,3.3) \dagger$ \\
\hline - use of an SFS before a night shift & $5.1(3.3,7.8)$ & $4.0(2.4,6.4) \dagger$ \\
\hline $\begin{array}{l}\text { success ot a nap Detore a night } \\
\text { shift }\end{array}$ & $0.51(0.30,0.87)$ & $0.46(0.25,0.83) \dagger$ \\
\hline - use of an SFS at other times & $6.9(4.1,11.6)$ & $4.7(2.6,8.4) \dagger$ \\
\hline \multicolumn{3}{|c|}{$\begin{array}{l}\text { OR = odds ratio; } \mathrm{Cl}=\text { confidence interval } \\
{ }^{*} \text { Adjusted for use of an SFS after a night shift (Yes/No), and use of an SFS at other times (Yes/No). } \\
\text { tAdjusted for use of a sleep-facilitating technique to help sleep before a night shift (Yes/No), use of an SFS before } \\
\text { a night shift (Yes/No), success of a nap before a night shift (Usually = Always, Most of the time and Some of the } \\
\text { time; Unusual = Exceptionally and Never), and use of an SFS at other times (Yes/No). }\end{array}$} \\
\hline
\end{tabular}


night shift are more likely to use them at other times. Successful sleep before a night shift decreases the use of SFSs after the night shift.

Acknowledgements: We acknowledge Dr. Barbara Cummins McManus for reviewing the manuscript.

Supported by a grant from the Canadian Association of Emergency Physicians.

Competing interests: None declared.

\section{References}

1. Kuhn G. Circadian rhythm, shift work, and emergency medicine. Ann Emerg Med 2001;37:88-98.

2. James M, Tremea M, Jones J. Can melatonin improve adaptation to night shift? Am J Emerg Med 1998;16:367-70.

3. Jorgensen K, Witting M. Does exogen melatonin improve day sleep or night alertness in emergency physicians working night shifts? Ann Emerg Med 1998;31:699-704.

4. Wright S, Lawrence L, Wreen K. Randomized clinical trial of melatonin after night-shift work: efficacy and neuropsychologic effects. Ann Emerg Med 1998;32:334-40.

5. Jockovich M, Cosentino D, Cosentino L, Wears RL, Seaberg DC. Effect of exogenous melatonin on mood and sleep efficiency in emergency medicine residents working night shifts. Acad Emerg Med 2000;7:955-8.

6. Winget C, De Roshia C, Markley $\mathrm{C}$, et al. A review of human physiological and performance changes associated with desynchronosis of biological rhythms. Aviat Space Environ Med 1984;55:1085-96.

7. Rutenfranz J, Knauth P, Colquhoun W. Hours of work and shiftwork. Ergonomics 1976;19:331-40.
8. Dominighetti G, Tomamichel M, Gutswiller F, Berthoud S, Casabianca A. Psychoactive drug use among medical doctors is higher than the general population. Soc Science Med 1991;33:269-74.

9. Rosvold EO, Vaglum P, Moum T. Use of minor tranquilizers (hypnotics and anxiolytics) among Norwegian physicians. A nation-wide comparative study. Soc Science Med 1998;46:581-90.

10. McAuliffe WE, Rohman M, Santangelo S, Feldman B, Magnuson E, Sobol A, et al. Psychoactive drug use among practicing physicians and medical students. N Engl J Med 1986;315:805-10.

11. Flaherty JA, Richman JA. Substance use and addiction among medical students, residents, and physicians. Psychiatr Clin N Am 1993;16:189-97.

12. Niedhammer I, Lert F, Marne MJ. Psychotropic drug use and shift work among French nurses (1980-1990). Psychol Med $1995 ; 25: 329-38$

13. Johnson EO, Roehrs T, Roth T, Breslau N. Epidemiology of alcohol and medication as aids to sleep in early adulthood. Sleep $1998 ; 21: 178-86$.

14. National Sleep Foundation. Sleep in America: A national survey of US adults. Princeton (NJ): The Gallup Organizations; 1991.

15. National Sleep Foundation. Sleep in America: A national survey of US adults. Princeton (NJ): The Gallup Organizations; 1995.

16. Pillitteri Jl, Kozlowski LT, Person DC, Spear ME. Over-thecounter sleep aids: widely used but rarely studied. J Subs Abuse 1994;6:315-23

Correspondence to: Dr. Benoit Bailey, Hôpital Ste-Justine, 3175, chem. Côte-Ste-Catherine, Montréal QC H3T 1C5; 514 345-4931 x6276, fax 514 345-4823, benoit.bailey@umontreal.ca 